\title{
Optimization of Phenanthrene-Degradation by Dietzia cinnamea AP for Bioremediation Applications
}

\author{
Zahra Fathi ${ }^{1}$, Golamhossein Ebrahimipour ${ }^{1}$, Amirarsalan Kavyanifard ${ }^{2 *}$, Ziba Najmi ${ }^{1}$ \\ ${ }^{1}$ Department of Microbiology, Faculty of Biological Sciences, Shahid Beheshti University, Tehran, Iran. \\ ${ }^{2}$ Department of Science, Payam Noor University (PNU), P.O. Box, 19395-3697, Tehran, Iran.
}

Received: 22 Apr 2016

Revised : 18 May 2016

Accepted: 2 Jun 2016

Corresponding Author:

Amirarsalan Kavynifard

Department of Science, Payam Noor

University (PNU), Tehran, Iran.

Phone: +982122431664

E-mail: kavyanifard@gmail.com

\begin{abstract}
Background: This study focused on isolation and identification of a Phenanthrene (Phe) degrader bacterium and optimization of environmental conditions for Phe degradation.

Materials and Methods: Enrichment technique was used for isolation and the most effective isolate; named AP was selected based on its Phe biodegradation abilities. The isolate was identified using morphological and biochemical tests as well as 16S rDNA sequencing. The effects of various factors such as temperature, $\mathrm{pH}$ and $\mathrm{C} / \mathrm{N}$ on bacterial growth and Phe degradation were investigated using protein assay (Bradford) and Gas Chromatography (GC), respectively.

Results: The selected isolate was identified as Dietzia cinnamea AP. It was able to degrade Phe at $\mathrm{pH}$ 6-10 (optimum at 8), temperatures of $25-45^{\circ} \mathrm{C}$ (optimum at $35{ }^{\circ} \mathrm{C}$ ) and $\mathrm{NH} 4 \mathrm{Cl}$ concentrations of 0.5-2.5 gL-1 (optimum at $2 \mathrm{~g} \mathrm{~L}-1$ ). By optimization of environmental parameters, within 10 days of fermentation, Phe degradation rate increased by more than 1.2 fold (from $60 \%$ to $73 \%$ ).

Conclusion: D. cinnamea AP was found to be an appropriate candidate for bioremediation applications. To the best of our knowledge, this is the first report of $D$. cinnamea species that can degrade Phe.
\end{abstract}

Keywords: Biodegradation, Phenanthrene, Dietzia cinnamea AP, Gas Chromatography

Please cite this article as: Fathi Z, Ebrahimipour G, Kavyanifard A, Najmi Z. Optimization of Phenanthrene-Degradation by Dietzia cinnamea AP for Bioremediation Applications. Res Mol Med. 2016; 4 (3): 22-28

\section{Introduction}

Polycyclic Aromatic Hydrocarbons (PAHs) are organic compounds containing two or more benzene rings. They are hazardous environmental contaminants that have noticeable biological effects, mutagenicity, carcinogenicity and toxicity (1). Phenanthrene (Phe) is a tri-cyclic aromatic hydrocarbon that is found in high concentrations in PAH contaminated surface soils, sediments and waste sites. Due to its potential severe hazards, Phe is of significant environmental concerns (2). Although Phe may undnnergo volatilization, photolysis, adsorption and chemical degradation but microorganisms play an effective role in its degradation in various ecosystems and microbial biodegradation is the main process in natural bioremediation (3). There are many bacterial species capable of degrading Phe and most of them are isolated from contaminated sediment or soils (4-6). It was found that microorganisms isolated from hydrocarbon contaminated soils are as active as or even more active than those isolated from uncontaminated soils (1). Phe biodegradation varies with the type and number of the microorganisms and the rate of biodegradation depends on $\mathrm{pH}$, temperature, accessibility of nutrients and chemical partitioning in growth medium $(7,8)$.

Natural biodegradation of hydrocarbons in polluted environments is extremely slow, therefore, for more efficient and rapid elimination of hydrocarbon pollutants, bioaugmentation strategy (adding bioscavengers to the polluted sites) can be applied (9). So, isolation of new bioscavengers and optimization of environmental condition have gained interests for 
their better performance. Although many Phe degrading bacteria have been isolated (10-13), more efficient Phe-degraders are always favored in bioremediation of Phe-contaminated sediments and soils (14). The main objective of this paper was to isolate bacterial strains which are able to degrade Phe and optimization of environmental parameters for more efficient removal of this contaminant.

\section{Materials and methods}

\section{Sampling}

Hydrocarbon contaminated soil samples were taken from oil exploration sites around Ahvaz, south of Iran; and transferred to laboratory in sterile bottles on ice while aerated every $20 \mathrm{~min}$. The sampling site $\mathrm{pH}$ and temperature were 7 and $40^{\circ} \mathrm{C}$, respectively.

\section{Media and chemicals}

1- A stock solution of Phe was achieved by dissolving $2 \mathrm{~g}$ of phe in $100 \mathrm{ml}$ acetone $(200 \mathrm{mg} \mathrm{L}$ 1). It was stored at $4{ }^{\circ} \mathrm{C}$ for further uses. Specific amounts of the stock were used, if necessary, for Phe and acetone solvent was first evaporated at any stage. 2- Mineral Salt Medium (MSM) included 36mM $\mathrm{NH} 4 \mathrm{Cl}, 1.69 \mathrm{mM}$ Kh2PO4, 0.066mM FeSO4, 16mM $\mathrm{MgSO} 4.7 \mathrm{H} 2 \mathrm{O}, 1.8 \mathrm{mM} \mathrm{CaCl} 2,0.67 \mathrm{mM} \mathrm{KCl}, 513 \mathrm{mM}$ $\mathrm{NaCl}$, along with $1 \mathrm{ml}$ of trace element solution. Trace element solution composed of $0.147 \mathrm{mM} \mathrm{ZnCl} 2$, $1.54 \mathrm{mM} \mathrm{CoCl} 2,0.77 \mathrm{mM} \mathrm{NiCl}, 1.38 \mathrm{mM} \mathrm{Na} 2 \mathrm{SeO} 4$, $0.24 \mathrm{mM}$ Na2MoO4, 0.118mM Na2WO4, $0.054 \mathrm{mM}$ $\mathrm{NaVO} 3$, and $0.007 \mathrm{mM} \mathrm{HCl}$. Final $\mathrm{pH}$ of MSM was adjusted at 7.0 using $100 \mathrm{mM}$ Tris/ $\mathrm{HCl}$ (15).

3- MSM agar contained 15g agar in 1L MSM. After distribution of the medium in plates and consolidation, whole surface of plates were coated by spreading a layer of Phe ( $2 \mathrm{ml}$ of Phe stock).

All the materials were supplied from Merck (Darmstadt, Germany); but Tris (Tris hydroxymethylamino methane), $\mathrm{CaCl}$, arabinose, starch, glucose, and Folin Phenol reagent were purchased from Sigma-Aldrich, Germany; Peptone, SIM and Agar from Difco, MRVP and TSI from Oxid; $\mathrm{MgSO} 4.7 \mathrm{H} 2 \mathrm{O}$ from Riedel-de Haën and $\mathrm{NH} 4 \mathrm{Cl}$ from Chemlab, Belgium.

\section{Isolation of Phe-degrading bacteria}

In order to isolate Phe-degrading bacteria, $10 \mathrm{~g}$ of samples were mixed with $100 \mathrm{ml}$ aseptic distilled water in $250 \mathrm{ml}$ flasks, shacked at $100 \mathrm{rpm}$ for 10 min and then, kept unshaken to precipitate. For enrichment of Phe degrading bacteria, $10 \mathrm{ml}$ of the supernatant was transferred into the conical flask containing $100 \mathrm{ml} \mathrm{MSM}$ and supplemented with 200 $\mathrm{mg} / \mathrm{L}$ Phe as the sole carbon and energy source $(\mathrm{pH} 7)$ and finally incubated at $30{ }^{\circ} \mathrm{C}$ for two weeks (40 $\mathrm{rpm}$ ). Phe consumption was monitored by increasing in bacterial biomass (absorbance at $600 \mathrm{~nm}$ ). Then, subcultures (four times) were performed by transferring $1 \mathrm{ml}$ of the enriched culture to the same fresh medium.

At the end of enrichment process, a 10-fold serial diluted concentration of inoculated MSM were made, cultured on MSM agar and incubated at $30{ }^{\circ} \mathrm{C}$. Colonies with clearing zone were purified and tested for Phe degradation ability as follow: equal concentration of any of colonies (an absorbance of 0.3 at $600 \mathrm{~nm}$ ) were inoculated in MSM and incubated at $30{ }^{\circ} \mathrm{C}$ for 10 days $(140 \mathrm{rpm})$. MSM with no bacterial inoculums was used as control. The experiments were conducted in triplicate. The amount of produced protein was considered as a criteria for bacterial growth and Phe degradation (8).

\section{Protein measurement}

Total produced protein was done as follows: at $48 \mathrm{~h}$ intervals, $1 \mathrm{ml}$ of fermented MSM was centrifuged at $8000 \mathrm{~g}$ for $10 \mathrm{~min}$. The harvested bacteria were then suspended in $1 \mathrm{ml}$ of Ringer's solution $(5.7 \mathrm{mM} \mathrm{KCl}$, $111.2 \mathrm{mM} \mathrm{NaCl}, 2.4 \mathrm{mM} \mathrm{NaHCO} 3$, and $2.25 \mathrm{mM}$ $\mathrm{CaCl} 2$ ), vortexed and centrifuged again (8000 $\mathrm{g}$ for $10 \mathrm{~min})$. In order to cell lysing, the pellet was resuspended in $0.5 \mathrm{ml}$ of $0.3 \mathrm{M} \mathrm{NaOH}$ and $1 \mathrm{ml}$ of distillated water and then vortexed. The suspension was incubated at $90^{\circ} \mathrm{C}$ for $1 \mathrm{~h}$. The achieved cell lysate was used to the total produced protein measuring that was done by dye-binding assay of Bradford. Bradford protein assay protocol was as follows: for Bradford reagent preparation, $100 \mathrm{mg}$ Coomassie Brilliant Blue G-250 was dissolved in 50 $\mathrm{ml} \mathrm{95 \%}$ ethanol, then after $100 \mathrm{ml}, 85 \%$ (w/v) phosphoric acid was added. The final volume of mixture was taken to 1 liter using $\mathrm{dH} 2 \mathrm{O}$, when the dye had completely dissolved, and filtered through Whatman 540 paper just before use. Finally, 20 $\mu$ l of the cell lysis was added to $1 \mathrm{ml}$ of the diluted reagent and vortexed. Absorbance of the formed blue color was measured at 595nm (Shimadzu, UV-120-02; Japan). The results were checked against the standard curve of a serial dilution series $(0.1-1.0 \mathrm{mg} / \mathrm{ml})$ of bovine serum albumin (16).

\section{Characterization of isolated bacterium}

To identify selected isolate, biochemical and morphological characterization were done according to Bergey's manual of determinative bacteriology (17). Phylogenetic identification was performed using $16 \mathrm{~S}$ rDNA analysis. Genomic DNA was extracted using phenol/chloroform/isoamyl alcohol referring (18) method. 16S rDNA gene fragment was amplified by PCR using a set of universal primer including Rd1 (5'-AGGAGGTGATCCAGCC-3') and Fd1 (5'AGAGTTTGATCCTGGCTCAG-3'). The PCR 
amplification mixture of $16 \mu 1$, contained the bacterial DNA (of about $200 \mathrm{ng}$ ), $5 \mu \mathrm{l}$ of Taq buffer (TAPS, pH 8.8, 3mM MgCl2, $50 \mathrm{mM} \mathrm{KCl),} 1 \mu \mathrm{l}(3$ units) of Taq DNA polymerase, $5 \mu \mathrm{l}$ of $2 \mathrm{mM} \mathrm{dNTP}$ $\operatorname{mix}$ and $5 \mu \mathrm{l}$ of each primer $(10 \mathrm{pM} / \mu \mathrm{l})$. The amplification program was set for 30 cycles; all included a denaturation at $960 \mathrm{C}(10 \mathrm{~s})$, an annealing at $50{ }^{\circ} \mathrm{C}(10 \mathrm{~s})$ and an extension step at $60{ }^{\circ} \mathrm{C}(4$ min); with a final extension step at $72{ }^{\circ} \mathrm{C}$ for $5 \mathrm{~min}$. Subsequently, PCR products were electrophoresed on $1 \%$ agarose gel and visualized using ethidium bromide. DNA fragments were sequenced using a sequencer (SEQLAB, Germany). Finally, all the sequences were compared with reference sequences in NCBI databases (http: //WWW.ncbi.nlm.nih. gov/Genbank) using Blast software. Phylogenetic analysis was done by MEGA software version 4 and genetic relationship was found based on the $16 \mathrm{~S}$ rDNA gene sequence using neighbor-joining tree with bootstrap value of 1000 replication.

\section{Optimization of Phe degradation}

Effects of environmental parameters such as temperature, $\mathrm{pH}$ and Carbon/Nitrogen (molar) ratio on Phe degradation and growth of the isolate was investigated. To determine the effect of temperature, log-phase cells (in $5 \mathrm{ml} \mathrm{MSM}$ ) were cultured at a range of temperatures $\left(25{ }^{\circ} \mathrm{C}\right.$ to $45{ }^{\circ} \mathrm{C}$ by $5{ }^{\circ} \mathrm{C}$ intervals) and shaken at $140 \mathrm{rpm}$. After determination of optimal temperature, in order to determine the effect of $\mathrm{pH}$ parameter, the $\mathrm{pH}$ of the MSM was adjusted from 6 to10, and temperature was adjusted at $35{ }^{\circ} \mathrm{C}$ with shaking at $140 \mathrm{rpm}$. Finally to determine the effect of $\mathrm{C} / \mathrm{N}$ ratio, various concentrations of $\mathrm{NH} 4 \mathrm{Cl}$ of 0.5 to $2.5 \mathrm{~g} / \mathrm{L}$ (with 0.5 $\mathrm{g} / \mathrm{L}$ intervals) were used while other condition was 35 ${ }^{\circ} \mathrm{C}$, pH8 and shaking at $140 \mathrm{rpm}$. The experiments were performed in triplicate. Sampling for protein assay was done at two-day intervals.

\section{Extraction and analysis of Phe by GC}

A 10-day-old fermented flask (containing $100 \mathrm{ml}$ MSM) under optimal conditions and a control flask (containing $100 \mathrm{ml} \mathrm{MSM}$ ) were extracted separately by ethyl acetate, and Phe amounts were measured by GC. The concentration of Phe was determined according to $\mathrm{Wu}$ et al. (19) $50 \mathrm{ml}$ ethyl acetate were added to the flask and was shaken for $15 \mathrm{~min}$. After forming two phases, Phe-containing organic phase was collected and aqueous phase was re-extracted by $50 \mathrm{ml}$ ethyl acetate. Eventually, the organic phase was dried by $\mathrm{Na} 2 \mathrm{SO} 4$ (anhydrous) and the volume was adjusted to $100 \mathrm{ml}$. Extract samples were analyzed using GC-FID equipped with a HP-5MS fused silica capillary column $(60 \mathrm{~m} \times 0.25 \mathrm{~mm}$ ID $\times$ $0.25 \mathrm{~lm}$ thicknesses, Agilent Technologies, USA) with the detector and injector temperature of $300{ }^{\circ} \mathrm{C}$ and $280{ }^{\circ} \mathrm{C}$, respectively. We used nitrogen as carrier gas. Oven temperature program was as following: 80 ${ }^{\circ} \mathrm{C}$ (for $2 \mathrm{~min}$ ) to $120{ }^{\circ} \mathrm{C}$ at a rate of $10{ }^{\circ} \mathrm{C} / \mathrm{min}$ and $120{ }^{\circ} \mathrm{C}$ to $300{ }^{\circ} \mathrm{C}$ at a rate of $4{ }^{\circ} \mathrm{C} / \mathrm{min}$ and held at $300{ }^{\circ} \mathrm{C}$ for15 min. The quantification and identification of chemicals were performed by matching their retention times of standards (20).

\section{Statistical analysis}

All experiments were done in triplicate and the values were expressed as means. In order to reveal any significant differences between the parameters and variables we used Kruskal-Wallis one-way analysis of variance, Kolmogorov-Smirnov test, U MannWhitney Test, or by one-way ANOVA and the Tukey test (SPSS software, version 19). Results were considered significant if $\mathrm{p}<0.05$.

\section{Results}

Isolation and selection of the most efficient Phedegrading bacterium

Three Phe degrading bacteria, named AP, BP and CP were isolated and purified by aforementioned enrichment and screening techniques. Compared with other isolates, the clear zone formed around AP isolate on MSM agar was the biggest, indicating that the isolate was the most efficient in Phe biodegradation. On the other hand, the amount of protein produced by AP strain was more than that of other isolates in MSM medium (Table 1). Thus, AP isolate was selected as the best Phe degrader strain and other next tests and analyses were done using that.

Table1. Results of screening and selection for most efficient Phe degrader bacterium.

\begin{tabular}{lccc}
\hline Isolate & AP & BP & CP \\
Produced protein $(\mathbf{m g} / \mathbf{g}$ Phe) & ${ }^{*} 29$ & 16 & 19 \\
Clear zone diameter $(\mathbf{m m})$ & 5 & 2.3 & 3.1
\end{tabular}

*showed significant difference than the other isolates statistically (using U Mann Whitney test).

\section{Characterization of selected bacterium}

For phylogenetic characterization of AP isolate, a fragment of $1442 \mathrm{bp}$ nucleotide of 16S rRNA was amplified and sequenced using universal primers and deposited in NCBI database (GenBank accession number: KR232837). As determined by BLAST analysis, a neighbor joining tree of the isolate was constructed (Figure 1). Results of NCBI blasting revealed that AP isolate clustered with Dietzia cinnamea strain DSM 44904, with 99\% nucleotide identity. AP isolate was also found to be closely related to other strains of $D$. cinnamea including 


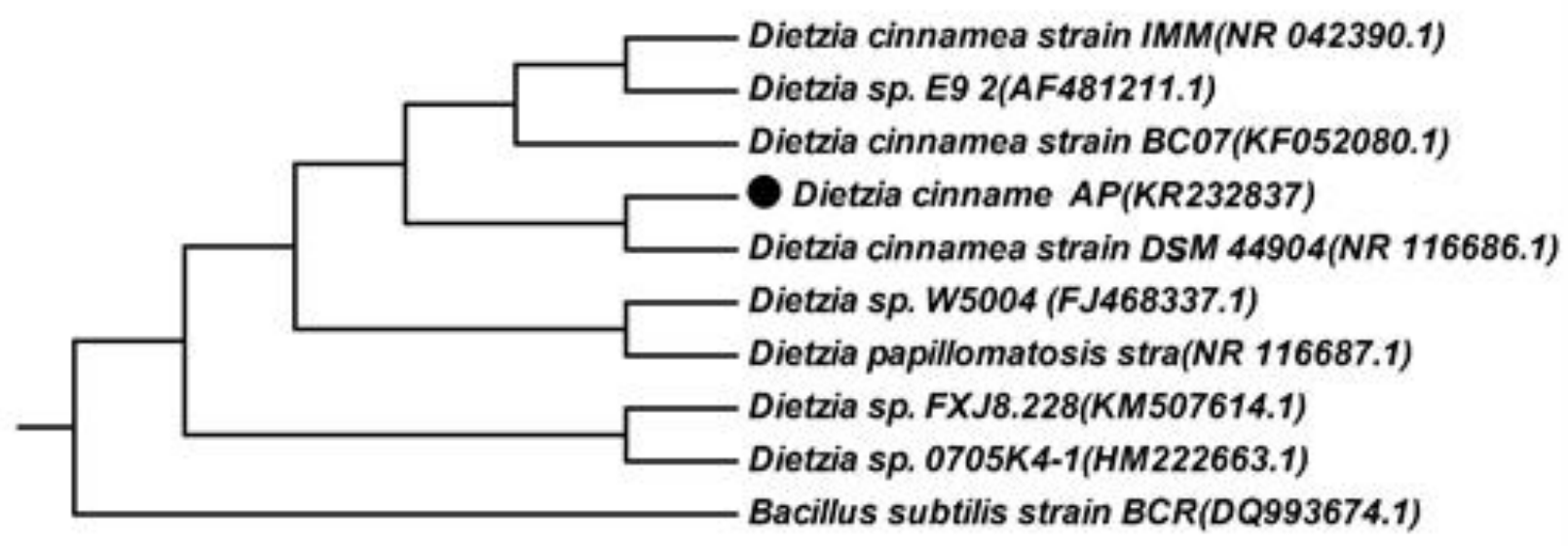

Figure 1. Phylogenic trees according to $16 \mathrm{~S}$ rRNA gene sequences illustrating the relationships between strain AP and other members of Dietzia genus and Bacillus subtilis strain BCR (DQ993674.1).

By comparing the phylogenetic analysis and results achieved from morphological and biochemical tests
(Table 2), the isolate was named as Dietzia cinnamea AP.

Table 2. Biochemical and morphological characteristics of isolate AP.

\begin{tabular}{|c|c|}
\hline Cell shape and properties & $\begin{array}{l}\text { Gram-positive, short rod and coccoid with size of 1.0-1.2 } \times 1.1-2.4 \text { (in single, double and multiple), non-spore or } \\
\text { capsule forming, non-motile }\end{array}$ \\
\hline Colony Morphology & convex, smooth-edge, circular, glistening and deep orange \\
\hline Positive reactions & oxidase, urease, catalase, arobic, nitrification, nitrate reduction and methyl-red \\
\hline Negative reactions & denitrification, acid-fast, $\mathrm{H}_{2} \mathrm{~S}$ production, Voges-Proskauer test and indole production \\
\hline Utilized & d-glucose, acetate, ethanol, d-fructose, glycerol, $n$-hexadecane, $n$-decane, maltose, d-xylose and starch \\
\hline Not utilized & d-arabinose, citrate, d-galactose, gelatin, lactose, mannose, raffinose and sucrose \\
\hline GC content & $71.6 \%$ \\
\hline Tolerated & $\mathrm{pH}(5-10)$, temperature $\left(15-48^{\circ} \mathrm{C}\right)$ and $\mathrm{NaCl}(0-9 \%)$ \\
\hline
\end{tabular}

Optimum conditions for Phe degradation by $D$. cinnamea $A P$

Environmental parameters including temperature, $\mathrm{pH}$ and $\mathrm{NH} 4 \mathrm{Cl}$ concentration were optimized to achieve maximal Phe degradation. As shown in Figure 2A, D. cinnamea AP was able to grow and degrade Phe at temperatures from $25{ }^{\circ} \mathrm{C}$ to $45{ }^{\circ} \mathrm{C}$, but with low efficiency at $25{ }^{\circ} \mathrm{C}$ and $45{ }^{\circ} \mathrm{C}$. Statistical analysis showed no significant differences between the amounts of protein produced at $35{ }^{\circ} \mathrm{C}$ and $40{ }^{\circ} \mathrm{C}$. Since more protein was produced at $35{ }^{\circ} \mathrm{C}$, the temperature considered as optimum for Phe degradation. In the case of $\mathrm{pH}$, it was observed that Phe degradation took place at the range of 6 to 9 by D. cinnamea AP (Figure 2B). Based on statistical analysis, D. cinnamea $\mathrm{AP}$ at $\mathrm{pH} 8$ showed a significant difference for Phe degradation compared with other values of $\mathrm{pH}$ and therefore selected as the optimum
$\mathrm{pH}$ for Phe degradation. Neither of growth or Phe degradation occurred at acidic $\mathrm{pH}(\mathrm{pH} 5)$. Overall, the isolate preferred alkaline values of $\mathrm{pH}$ than acidic values. The selected bacterium grew and degraded Phe in concentration ranges of 1 to $2.5 \mathrm{~g} / \mathrm{L} \mathrm{NH} 4 \mathrm{Cl}$. No significant differences were observed btween concentrations of 2 and $2.5 \mathrm{~g} / \mathrm{L} \mathrm{NH} 4 \mathrm{Cl}$, statistically, but these concentrations differed from other concentrations. Since minimum amount of $\mathrm{NH} 4 \mathrm{Cl}$ is desired in industrial experiences, therefore the amount of $2 \mathrm{~g} / \mathrm{L} \mathrm{NH} 4 \mathrm{Cl}$ was considered as optimum concentration for $\mathrm{NH} 4 \mathrm{Cl}$ (Figure 2C). At lower concentrations of $\mathrm{NH} 4 \mathrm{Cl}$, the rates of growth and Phe degradation decreased as $\mathrm{NH} 4 \mathrm{Cl}$ concentrations decreased. Figure 2D shows that optimization of environmental parameters resulted in increasing of total produced protein more than 1.5 fold (from 78.24 to $125 \mu \mathrm{g} / 200 \mathrm{mg}$ Phe). Since increase in protein 
produced was a criterion for Phe degradation, it can be concluded that the rate of Phe degradation
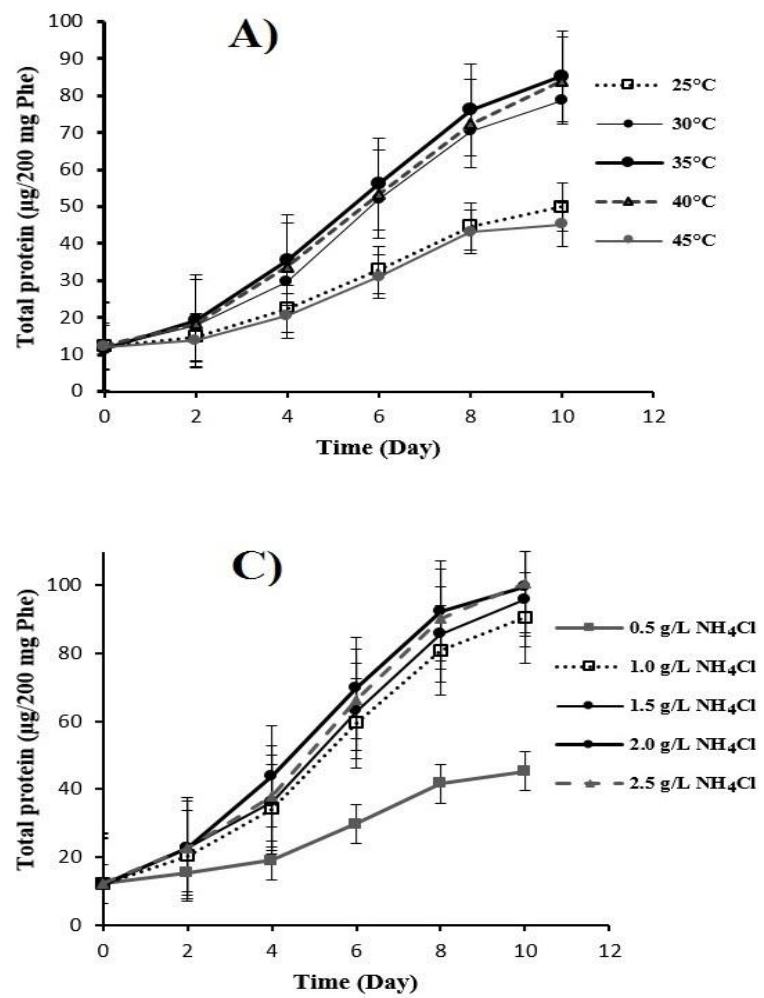

increased by environmental parameters optimization.
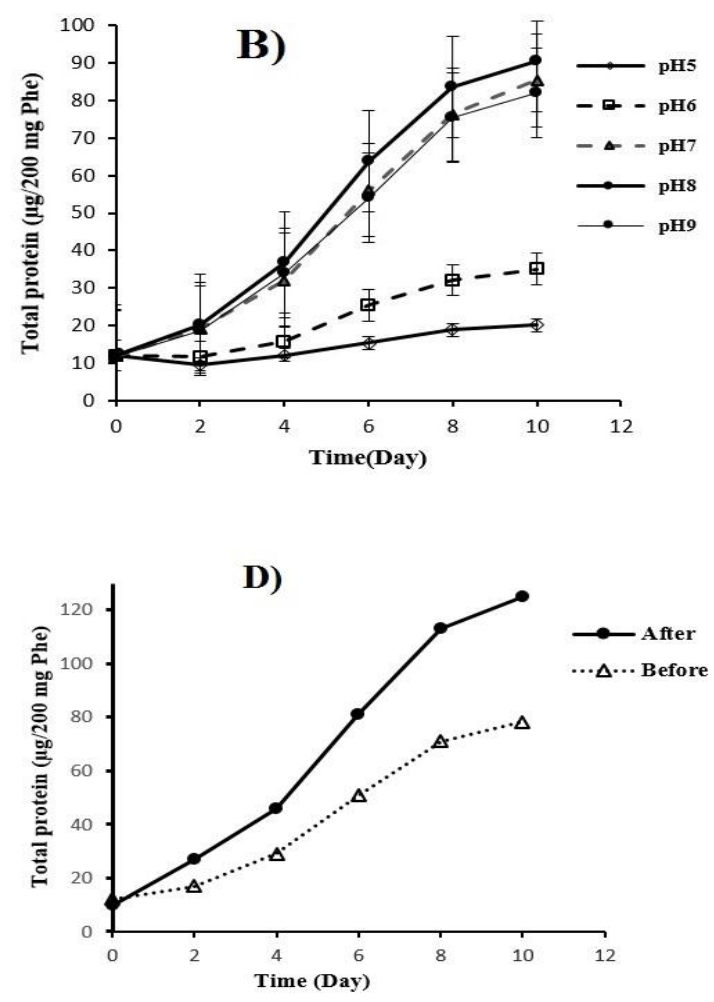

Figure 2. Optimization of Phe degradation by $D$. cinnamea AP. A) Effect of different temperatures on bacterial growth in MSM at pH 7 and $1 \mathrm{~g} / 1$ $\mathrm{NH} 4 \mathrm{Cl}$. B) Effect of different $\mathrm{pH}$ on bacterial growth in MSM at $35{ }^{\circ} \mathrm{C}$ and $1 \mathrm{~g} / 1 \mathrm{NH} 4 \mathrm{Cl}$. C) Effect of different $\mathrm{NH} 4 \mathrm{Cl}$ concentrations on bacterial growth in MSM at $35^{\circ} \mathrm{C}$ and $\mathrm{pH}$ 8. D) Effect of optimization on amounts of protein produced by D. cinnamea AP.

Before optimization of environmental factors, $D$. cinnamea AP was able to degrade only $60 \%$ of Phe at 10-day incubation; but after optimization of environmental factors the value of Phe degradation

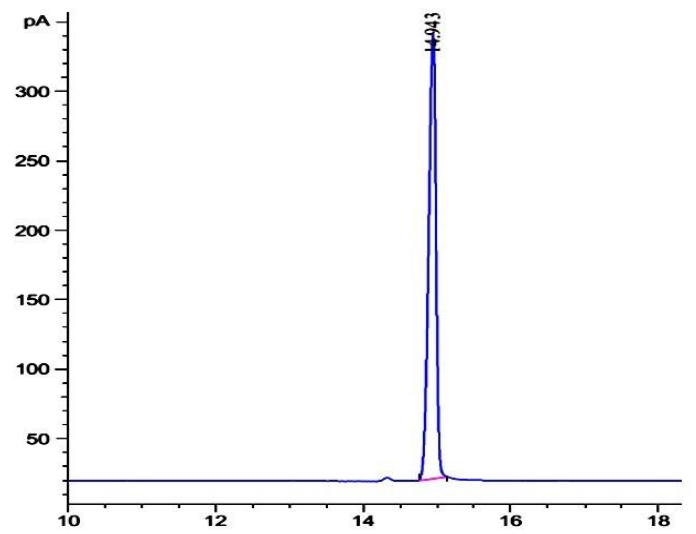

raised to $73 \%$. These were proved by GC analysis of remained Phe in 10-day-old fermented MSM under optimized (Figure 3).

Figure 3. GC analysis showing Phe consumption by D. cinnamea AP. Phe values in control MSM (left) and in optimized MSM after 10-days of incubation (right).

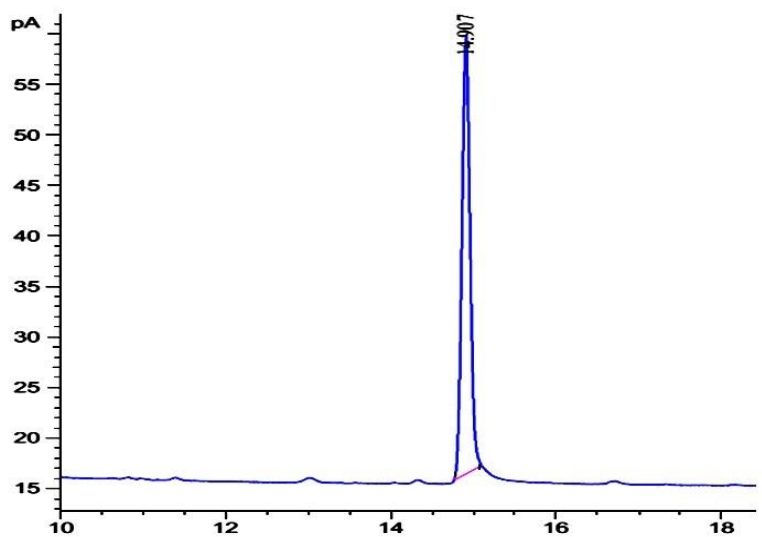

azems.ar

Res Mol Med, 2016; 4 (3): 26 


\section{Discussion}

High concentrations of Phe in PAHs contaminated sediments and their potential bioaccumulation and severe hazards, calls for developing a safe procedure for their removal from contaminated sites. Therefore, great attention has been paid to develop effective methods to remediate PAHs contaminated environments in the past decades (14).

We successfully isolated three Phe degrader bacterial strains, amongst which one (named AP) was the most efficient and selected for Phe degradation. Based on biochemical morphological and tests as well as $16 \mathrm{~S}$ rDNA sequencing, our isolate was characterized as Dietzia cinnamea AP. Some members of Dietzia species have been revealed to degrade aromatic compounds (21) and Phe degrader members in Dietzia genus have been reported (22-24). For example, two $D$. cinnamea strains were found to have tendency for n-C11 to n-C36 $(25,26)$ and n-C10 to nC26 (17) alkanes hydrocarbon biodegradation. Despite the ability of these strains to degrade alkanes hydrocarbon, they were unable to degrade Phe as the sole carbon and energy source; while $D$. cinnamea AP could use Phe as the sole carbon and energy source. Based on our current knowledge we can claim that present study is the first report of Phe degradation by $D$. cinnamea species.

Since environmental parameters affect various activities of organisms $(27,28)$ including their ability to degrade and utilize various compounds, additional studies were made to determine optimal conditions for maximum Phe degradation by the bacterium. Total protein produced was considered as a criterion for growth and therefore Phe degradation. Our results showed that $D$. cinnamea AP degraded $\mathrm{Phe}$ at a wide range of $\mathrm{pH}$ (6 to10), temperature $\left(25-45{ }^{\circ} \mathrm{C}\right)$ and $\mathrm{NH} 4 \mathrm{Cl}$ concentration (0.5-2.5 gL-1). Optimization of environmental parameters led to increase in performance of Phe degradation by our isolate. This increase was proven by total protein produced and GC analysis. Precise measurements achieved from GC analysis showed that Phe degradation rate increased more than 1.2 fold (from $60 \%$ to $73 \%$ ) by optimization of environmental parameters. Acceptable Phe degradation rates were achieved by the bacterium under wide ranges of environmental parameters, therefore, it could be suggested as a versatile candidate for bioremediation applications in various media including acidic or alkaline environments at variable temperatures.

To the best of our knowledge this is the first report of Phe degradation by $D$. cinnamea species as sole carbon and energy source. According to the results, D. cinnamea AP could be valuable in bioremediation of Phe-contaminated environments.

\section{Acknowledgments}

This work was funded by Shahid Beheshti University of Tehran, Microbiology Laboratory of Industrial Biotechnology.

\section{Authors' contributions}

All the authors performed the experiments. EG supervised the study. NZ advised the study KA wrote the manuscript. All authors discussed the data and commented on the manuscript.

\section{Conflict of interest}

The authors declare that they have no conflict of interest in this work.

\section{References}

1. Al-Awadhi H, Sulaiman RH, Mahmoud HM, Radwan S. Alkaliphilic and halophilic hydrocarbon-utilizing bacteria from Kuwaiti coasts of the Arabian Gulf. Appl microbiol biotechnol. 2007; 77(1):183-6. PMID: 17710391

2. Kavyanifard A, Ebrahimipour GH, Ghassempour A. Individually and Synergistic Degradation of Hydrocarbons by Biosurfactant Producing Bacteria. Res Mol Med. 2016; 4 (1):3644. doi 10.7508/rmm.2016.01.006

3. Andreoni V. Gianfreda L. Bioremediation and monitoring of aromatic-polluted habitats. Appl Microbiol Biotechnol. 2007; 76(2):287-308. PMID: 17541581

4. Bihari Z, Szvetnik A, Szabó Z, Blastyák A, Zombori Z, Balázs $\mathrm{M}$, et al. Functional analysis of long-chain n-alkane degradation by Dietzia spp. FEMS Microbiol Letters. 2011; 316(2):100-107. PMID: 21204932

5. Bødtker G, Hvidsten IV, Barth T, Torsvik T. Hydrocarbon degradation by Dietzia sp. A14101 isolated from an oil reservoir model column. Antonie Van Leeuwenhoek 2009; 96(4):459-469. PMID: 19565350

6. Chang CH, Lee J, Ko BG, Kim SK, Chang JS. Staphylococcus sp. KW-07 contains nahH gene encoding catechol 2 3-dioxygenase for phenanthrene degradation and a test in soil microcosm. Int Biodeterior Biodegrad. 2011; 65(1):198-203.

7. Zhu X, Ni X, Waigi MG, Liu J, Sun K, Gao Y. Biodegradation of Mixed PAHs by PAH-Degrading Endophytic Bacteria. Int J Environ Res Public Health. 2016; 13: 805. PMID: 27517944

8. Gu H, Lou J, Wang $\mathrm{H}$, Yang $\mathrm{Y}$, Wu L, Wu J, Xu J. Biodegradation, Biosorption of Phenanthrene and Its TransMembrane Transport by Massilia sp. WF1 and Phanerochaete chrysosporium. Front Microbiol. 2016; 7:38. PMID: 26858710

9. Chen J, Wong M, Wong YS, Tam NF. Multi-factors on biodegradation kinetics of polycyclic aromatic hydrocarbons (PAHs) by Sphingomonas sp. a bacterial strain isolated from mangrove sediment. Mar Pollut Bull. 2008; 57(6):695-702. PMID: 18433800

10. Coulon F, McKew BA, Osborn AM, McGenity TJ, Timmis KN. Effects of temperature and biostimulation on oil-degrading microbial communities in temperate estuarine waters. Environ Microbiol. 2007; 9(1):177-186. PMID: 17227422

11. Díaz MP, Boyd KG, Grigson SJ, Burgess JG. Biodegradation 
of crude oil across a wide range of salinities by an extremely halotolerant bacterial consortium MPD-M immobilized onto polypropylene fibers. Biotechnol Bioengin. 2002; 79(2):145-153. PMID: 12115430

12. Ebrahimipour GH, Gilavand F, Karkhane M, Kavyanifard AA, Teymouri M, Marzban A. Bioemulsification activity assessment of an indigenous strain of halotolerant Planococcus and partial characterization of produced biosurfactants. Int J Environ Sci Technol. 2014. doi 10.1007/s13762-014-0548-5

13. Gharibzahedi SMT, Razavi SH, Mousavi M. Potential applications and emerging trends of species of the genus Dietzia: a review. Ann of Microbiol. 2014; 64(2):421-429.

14. Wang H, Lou J, Gu H, Luo X, Yang L, Wu L, Liu Y, Wu J, Xu J. Efficient biodegradation of phenanthrene by a novel strain Massilia sp. WF1 isolated from a PAH-contaminated soil. Environ Sci Pollut Res Int. 2016; 23(13):13378-88. PMID: 27026540

15. Holt JG, Krieg NR, Sneath PH, Staley JT, Williams ST. Bergey's Manual of determinate bacteriology. 1994.

16. Noble JE, Bailey MJA. Quantitation of Protein. Methods Enzymol. 2009; 463:73-95. PMID: 19892168

17. Jiang L, Song M, Luo C, Zhang D, Zhang G. Novel phenanthrene-degrading bacteria identified by DNA-stable isotope probing. PloS one. 2015; 10(6):e0130846. PMID: 26098417

18. Kavynifard A, Ebrahimipour G, Ghasempour A. Optimization of crude oil degradation by Dietzia cinnamea KA1 capable of biosurfactant production. J Basic Microbiol. 2015; 55. PMID: 26615815

19. Kucerova R, Fecko P. Biodegradation of PAU PCB and NEL soil samples from the hazardous waste dump in Pozd'átky (Czech Republic) Physicochem. Prob Miner Process. 2006; 40:203-210.

20. Moscoso F, Teijiz I, Sanroman M, Deive F. On the suitability of a bacterial consortium to implement a continuous PAHs biodegradation process in a stirred tank bioreactor. Indust Engin Chem Res. 2012; 51(49):15895-900.
21. Reda A.B. Bacterial bioremediation of polycyclic aromatic hydrocarbons in heavy oil contaminated soil. J Appl Sci Res. 2009 pp. 197-201.

22. Sambrook J, Fritsch E, Maniatis T. Molecular Cloning: A Laboratory Manual 1989. Cold Spring Harbor Laboratory New York. 2001

23. Vinas M, Sabaté J, Espuny MJ, Solanas AM. Bacterial community dynamics and polycyclic aromatic hydrocarbon degradation during bioremediation of heavily creosotecontaminated soil. Appl Environ Microbiol. 2005; 71(11):70087018. PMID: 16269736

24. Wang XB, Chi CQ, Nie Y, Tang YQ, Tan Y, Wu G, Wu XL. Degradation of petroleum hydrocarbons (C6-C40) and crude oil by a novel Dietzia strain. Bioresour Technol. 2011; 102(17):77557761. PMID: 21715162

25. Wu YR, Luo ZH, Vrijmoed L. Biodegradation of anthracene and benz [a] anthracene by two Fusarium solani strains isolated from mangrove sediments. Bioresour Technol. 2010; 101(24):9666-9672. PMID: 20691587

26. Kavynifard A, Ebrahimipour G, Ghasempour A. Structure Characterization of a Methylated Ester Biosurfactant Produced by a Newly Isolated Dietzia cinnamea KA1. Microbiol. 2016; 85(4):430-435. doi 10.1134/S0026261716040111

27. Hassan I, Mohamedelhassan E, Yanful EK, Yuan ZC. A Review Article: Electrokinetic Bioremediation Current Knowledge and New Prospects. Adv Microbiol. 2016; 6:57-72.

28. de la Cueva SC, Rodríguez CH, Cruz NOS, Contreras JAR, Miranda JL. Changes in Bacterial Populations During Bioremediation of Soil Contaminated with Petroleum Hydrocarbons. Water Air Soil Pollut. 2016; 227: 91. doi:10.1007/s11270-016-2789-z 